\title{
PENGARUH KINERJA EKONOMI MAKRO TERHADAP NILAI TUKAR PETANI
}

\author{
Azhar Bafadal \\ Jurusan Agribisnis, Fakultas Pertanian, Universitas Halu Oleo \\ Kampus Hijau Bumi Tridharma Anduonohu, \\ Kendari 93232 Sulawesi Tenggara \\ Email: azharbafadal@yahoo.com
}

\begin{abstract}
This study aims to analyze the effect of macroeconomic performance, i.e., the inflation and gross regional domesticproduct of agriculture sector (PDRB), on the farmer's term of trade (NTP) in Southeast Sulawesi. Data used are of quarterly, covering 2006-2012. The analysis is undertaken by using a multiple linear regression withordinary least squaresestimation method(OLS). The results showed that the inflation has a significant effecton the farmer's term oftrade. The effect of the inflation on the farmer's term of trade is responsive, the inflation of 1 $\%$ will be able to decrease thefarmer's term of trade at $1.61 \%$. Agricultural Sector PDRB does not significant affecton thefarmer's term of trade. This study implies that the inflation control is an important task for the government so that the effect of inflation does not result in a sharp decrease in NTP.
\end{abstract}

Keywords: Macroeconomic, inflation, Farmer's term of trade, Gross regional domestic product of agriculture sector

\section{PENDAHULUAN}

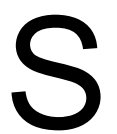

ektor pertanian berperan sangat penting dalam pembangunan nasional antara lain melalui penyediaan kebutuhan pangan pokok, perolehan devisa melalui ekspor, penampung tenaga kerja khususnya di daerah pedesaan.Terlepas dari keberhasilan yang telah dicapai dan peran strategis sektor pertanian, tantangan pembangunan pertanian saat ini dan mendatang dirasakan semakin berat.Oleh karena itu, arah kebijakan harus lebih menekankan kepada ekonomi kerakyatan yang secara langsung melibatkan petani.

QE Journal | Vol.03 - No.03 September 2014 - 162 
Pengembangan pertanian seyogyanya dilakukan dengan menggunakan pendekatan dalam rangka meningkatkan kualitas masyarakat pedesaan.Argumen ini sesuai pendapat Nchuchuwe and Adejuwon, (2012) yang menyatakan bahwa dalam upaya memfasilitasi pembangunan pertanian, pemerintah seharusnya mengadopsi pendekatan pembangunan pedesaan yang terintegrasi dengan dimana menggunakan strategi multidimesi untuk meningkatkan kualitas hidup masyarakat pedesaan.Salah satu indikator yang bisa dipakai untuk melihat kesejahteraan petani adalahNilai Tukar Petani (NTP).Nilai tukar petanimerupakan perbandingan indeks harga yang diterima petani terhadap indeks harga yang dibayar petani dan dinyatakan dalam persentase.Indikator ini merupakan salah satu indikator untuk melihat tingkat kemampuan atau daya beli petani di pedesaan.Selain itu, NTP juga menunjukkan daya tukar dari produk pertanian dengan barang dan jasa yang dikonsumsi maupun untuk biaya produksi.Semakin tinggi NTP, secara relatif semakin kuat pula tingkat kemampuan atau daya beli petani.

Faktor yang sangat berpengaruh terhadap kemampuan daya beli masyarakat khususnya petani itu sendiri adalah faktor inflasi.Inflasi didefinisikan sebagai kenaikan harga umum yang berlangsung secara terus menerus.Inflasi dapat memperburuk distribusi pendapatan.Peningkatan harga sering mendahului kenaikan pendapatan sehingga inflasi cenderung menimbulkan kemerosotan pendapatan riil, dengan demikian menurunkan taraf kesejahteraan masyarakat.

Indikator penting untuk mengetahui kondisi ekonomi disuatu wilayah dalam suatu periode tertentu dapat digambarkan oleh kinerjaProduk Domestik Regional Bruto (PDRB), baik atas dasar harga berlaku maupun atas dasar harga konstan. Besaran PDRB tersebut menunjukkan jumlah nilai tambah yang dihasilkan oleh seluruh unit usaha dalam suatu wilayah tertentu, atau merupakan nilai barang dan jasa akhir yang dihasilkan oleh seluruh unit ekonomi.SedangkanPDRB pertanian mencerminkan nilai tambah hasil-hasil sektor pertanian secara keseluruhan.Meningkatnya hasil sektor pertanian secara langsung akan meningkatkan pendapatan pada sektor tersebut dan diharapkan mampu memberikan perbaikan kesejahteraan pada pihak petani. Laju inflasi, PDRB sektor pertanian dan NTP Sultra disajikan pada Tabel 1.Inflasi cenderung berfluktuasi dan NTP 
relatif konstan di beberapa tahun terakhir, sementara PDRB Pertanian cenderung meningkat dari waktu ke waktu.

Tabel 1. Laju Inflasi, PDRB Sektor Pertanian dan Nilai Tukar Petani di Sulawesi Tenggara,tahun 2008-2012

\begin{tabular}{ccccc}
\hline No & Tahun & Inflasi (\%) & $\begin{array}{c}\text { PDRB Pertanian ADHB } \\
\text { ( Rp T) }\end{array}$ & NTP \\
\hline 1 & 2008 & 15,28 & 8,10 & 102,60 \\
2 & 2009 & 4,60 & 8,98 & 109,93 \\
3 & 2010 & 3,87 & 9,42 & 107,32 \\
4 & 2011 & 5,09 & 10,27 & 107,47 \\
5 & 2012 & 4,03 & 11,35 & 106,23 \\
\hline
\end{tabular}

Sumber : BPS

Tujuan penelitian ini adalah untuk mengetahui pengaruh kinerja ekonomi makro yaitu inflasi dan produk domestik regional bruto (PDRB) sektor pertanian terhadap nilai tukar petani (NTP) di Sulawesi Tenggara.

Inflasi merupakan suatu keadaan dimana terjadi kenaikkan harga-harga secara (tajam) absolute yang berlangsung terus menerus dalam jangka waktu cukup lamaKhalwaty (2000). Inflasi adalah proses kenaikan harga umum barang-barang secara terus menerus, dan hal ini tidak berarti bahwa harga-harga berbagai macam barang itu naik dengan persentase yang sama, dimana kenaikkannya tidaklah bersamaan yang penting terdapat kenaikkan harga secara terus menerus selama satu periode tertentu.

Menurut Boediono (1993), inflasi adalah kecenderungan dari kenaikkan harga-harga secara umum dan terus-menerus, hal ini tidak berarti bahwa harga berbagai macam barang itu naik dengan persentase yang sama.Mungkin dapat terjadi kenaikan tersebut tidaklah bersamaan,yang penting terdapat kenaikkan harga umum barang secara terus menerus selama satu periode.Sedangkan untuk melihat inflasi dapat dibedakan berdasarkan laju pertumbuhan IHK (Indeks Harga Konsumen) tersebut yang berdasarkan atas parah atau tidaknya inflasi yaitu inflasi ringan, inflasi sedang dan inflasi berat.

Tingkat inflasi adalah suatu indikator perubahan kenaikan harga-harga umum. Untuk mengukur kenaikan tingkat harga-harga umum atau 
tingkat inflasi digunakan indeks harga yang pengukurannya dapat dilakukan dengan tiga cara yakni indeks Harga konsumen (IHK), Indeks Harga Pedagang Besar (IHPB) dan Produk Nasional Bruto (PNB) deflator.

Menurut Waluyo (2006) dan Khalwati (2000) bahwapenghitungan inflasi yang paling banyak digunakan adalah dengan menggunakan perubahan indeks harga konsumen (IHK).Hal ini disebabkan data indeks harga konsumen daoat diperoleh dalam bentuk bulanan, triwulan, atau tahunan.Untuk Indonesia data indeks harga konsumen cukup mudah diperoleh baik dari laporan Badan Pusat Statistik (BPS), Bank Indonesia (BI) ataupun lembaga lainnya.Model dari indeks harga konsumen adalah sebagai berikut :

$$
\begin{aligned}
& \operatorname{Inf}_{\mathrm{t}=} \frac{\left(\mathrm{IHK}_{\mathrm{t}}-\mathrm{IHK}_{\mathrm{t}-1}\right)}{\mathrm{IHK}} \times 100 \% \\
& \text { dengan, } \\
& \quad \mathrm{Inf}_{\mathrm{t}-1}=\text { Laju Inflasi pada tahun } \mathrm{t} \\
& \quad \mathrm{IHK}_{\mathrm{t}}=\text { Indeks harga konsumen periode } \mathrm{t} \\
& \quad \mathrm{IHK}_{\mathrm{t}-1}=\text { Indeks harga konsumen } \mathrm{t}-1
\end{aligned}
$$

Sinuhaji (2006)mencoba menganalisis hubungan antara inflasi dan tingkat pengangguran di Indonesia. Penelitian ini bertujuan untuk mengetahui perkembangan inflasi dan pengangguran dan arah hubungan kedua variabel tersebut. Alat analisis yang digunakan yaitu Granger causality test selama kurun waktu 1971-2004.Dalam penelitian ini ditemukan hubungan yang searah yaitu tingkat inflasi mempengaruhi tingkat pengangguran. Hasil penelitian menunjukkan bahwa tingkat kenaikan inflasi1\% (ceteris paribus) akan mendorong tingkat pengangguran sebesar $0,28 \%$.

Menurut Mankiw (2003), dampak inflasi yang ditimbulkan akan mengakibatkan beberapa biaya sosial, baik biaya inflasi yang diharapkan dan biaya inflasi yang tidak diharapkan. Sedangkan menurut Sukirno (1998), inflasi akan membawa dampak terhadap perekonomian suatu negara.Adapun akibat buruk dari inflasi di bedakan dalam dua aspek yaitu akibat buruk kepada perekonomian dan akibat buruk kepada individu-individu atau masyarakat.Tingkat inflasi yang tinggi menurunkan produksi yang mana inflasi mengakibatkan terjadinya kenaikan harga bahan baku dan kenaikan upah buruh sehingga kalkulasi harga pokok akan meninggikan harga jual produk lokal (Waluyo, 2006). 
Dilain pihak, turunnya daya beli masyarakat terutama yang berpenghasilan tetap akan mengakibatkan tidak semua barang dan jasa habis terjual.

Suparmoko (2000) mengatakan bahwa dalam masa hiperinflasi harga meningkat secara cepat, para penerima pendapatan tetap, seperti pegawai negeri ataupun karyawan dan karyawati swasta serta kaum buruh akan menjadi kewalahan dalam mengimbangi kenaikan harga barang dan jasa, sehingga taraf hidup mereka menjadi semakin merosot dari waktu ke waktu. Hal ini pun didukung oleh Sukirno (1999) yang menyatakan bahwa dalam situasi inflasi bagi sebagian masyarakat yang berpenghasilan tetap, peningkatan harga sering mendahului kenaikan pendapatan sehingga inflasi cenderung menimbulkan kemerosotan pendapatan riil, dengan demikian menurunkan taraf kesejahteraan masyarakat.

Pendapatan nasional adalah istilah yang menerangkan tentang nilai barang dan jasa yang diproduksi oleh suatu negara dalam suatu tahun tertentu.Menurut Mankiw (2003),Produk Domestik Bruto (PDB) adalah nilai pasar dari suatu barang jadi atau jasa yang diproduksi oleh suatu negara selama kurun waktu tertentu.Dalam konsep yang spesifik pengertian produk nasional atau pendapatan nasional dibedakan menjadi dua pengertian yaitu Produk Nasional Bruto (PNB) dan Produk Domestik Bruto. Produk nasional yang diwujudkan oleh warga negara suatu negara dinamakan Produk Nasional Bruto, sedangkan produk nasional yang diwujudkan oleh penduduk dalam suatu negara tersebut Produk Domestik Bruto.Pada hakikatnya PNB dan PDB merupakan ukuran bagi besarnya kemampuan suatu negara untuk menghasilkan barang dan jasa dalam suatu tahun tertentu.Sedangkan produk atau pendapatan suatu daerah (misal provinsi) disebut dengan Produk Domestik Regional Bruto (PDRB).

Pembangunan pertanian di Indonesia, diartikan pada berkembangnya pertanian yang maju, efisiensi dan tangguh mencangkup konsep-konsep makro yakni dalam hubungannya dengan pertanian itu sendiri maupun dengan sektor-sektor lain diluar pertanian.Indikator yang dipakai untuk mengevaluasi kinerja pembangunan sektor pertanian di daerah antara lain PDRB sektor pertanian, penyerapan tenaga kerja, dan peranannya menurunkan jumlah penduduk miskin.Sebagai negara agraris maka bidang yang paling mendapat prioritas dalam pembangunan ekonomi adalah bidang sektor pertanian, hal ini disebabkan karena sektor tersebut

QE Journal |Vol.03 - No.03 September 2014 - 166 
dipandang dari berbagai segi merupakan sektor yang dominan dalam perekonomian, misalnya kontribusinya dalam pembentukan nilai PDRB, kontribusinya dalam menghasilkan devisa dan penyediaan lapangan kerja bagi penduduk.

Sektor pertanian mempunyai peranan yang penting dalam perspektif ekonomi makro.Hal ini disebabkan pertama, sektor pertanian merupakan sumber pertumbuhan output nasional yang penting, kedua, sektor pertanian memiliki karakteristik spesifik sebagai sektor tradisonal dalam perekonomian Sulawesi Tenggara. Dalam kaitan menurunnya kontribusi sektor pertanian dalam perekonomianmaka dapat diasosiasikan dengan hukum Engle. Hukum Engle menyatakan bahwa jika pendapatan meningkat maka proporsi pengeluaran terhadap bahan-bahan makanan akan makin menurun, ataudengan kata lain bahwa elastisitas permintaan terhadap makanan lebih kecil dari satu (inelastis).Fungsi sektor pertanian yang paling penting dalam perekonomian adalah untuk menyediakan bahan-bahan makanan, maka peningkatan permintaan terhadap bahan makanan, tidaklah besar permintaan terhadap barang-barang hasil sektor industri dan jasa.Menurut Zhang and Fan (2002) bahwa investasi publik memiliki kontribusi terhadap pertumbuhan produksi dalam sektor pertanian dan sektor non pertanian pedesaan. Penelitian yang dilakukan oleh Ele, et al. (2014) memperlihatkan keterkaitan antara pengeluaran belanja publik untuk modal pertanian dengan pertumbuhan ekonomi pertanian di Nigeria.Hasil penelitian tersebut menunjukkan bahwa pengeluaran modal pada sektor pertanian memberikan dampak positif terhadap pertumbuhan ekonomi sektor pertanian.

Kinerja makroekonomi banyak dipengaruhi kebijakan fiskal yang diambil oleh pemerintah. Kajian mengenai kebijakan pemerintah yang terkait dengan sektor pertanian dilakukan oleh Akhmad, et al., (2013) dimana hasilnya menunjukkan bahwa kebijakan fiskal pemerintah daerah terutama pada belanja modal pada sektor pertanian atau sektor pertanian lainnya dapat menstimulus investasi swasta. Selain itu, beberapa kajian tentang kebijakan pemerintah terhadap sektor pertanian dilakukan oleh Uger (2013) dan Akintunde, et al. (2013). Sedangkan kajian yang menelaah dampak kebijakan fiskal terhadap biaya input dan produksi pertanian di Albania dilakukan oleh (Zhllima, et al., 2013). 
Salah satu indicator tingkat kesejahteraan petani dan keadaan perekonomianpedesaan adalahNTP. Besaran NTP dapat mengukur kemampuan atau daya tukar sektor pertanian terhadap sektor non pertanian. Nilai tukar petani merupakan proxy untuk mengukur tingkat kesejahteraan petani, sebagaimana yang dikaji oleh Bhagat (2013).Fluktuasi NTP menunjukkan fluktuasi kemampuan riil petani dan mengindikasikan kesejahteraan petani (Suyono, 2001).

Erison (2004) menyatakan bahwa harga yang diterima petani pada NTP adalah harga hasil produksi ditingkat petani, sementara harga yang dibayar petani terdiri dari komponen biaya konsumsi rumah tangga (konsumsi pangan dan non pangan) dan biaya sarana produksi.Harga yang diterima petani merupakan rata-rata harga produsen atas hasil produksi petani yang merupakan rata-rata harga produsen atas hasil produksi petaniyang merupakan rataan harga yang diterima disawah.Harga rata-rata adalah tingkat harga, yang apabila dikalikan dengan volume penjualan akan merupakan nilai uang yang diterima petani.Harga tersebut merupakan harga dari hasil produksi petani sebelum dimasukkan biaya transportasi atau, pengangkutan dimana biaya pengepakan ke dalam harga penjualannya.Selanjutnya dijelaskan bahwa harga yang dibayar petani merupakan harga yang tertimbang dari harga biaya konsumsi makanan, konsumsi non makanan dan biaya produksi serta penambahan barang modal dari barang yang dikonsumsi atau dibeli petani.Harga yang dimaksud adalah harga eceran atau jasa dipasar pedesaan.

Indeks harga yang diterima petani digunakan untuk mengetahui fluktuasi harga komoditas pertanian yang dihasilkan petani, sedangkan indeks harga yang dibayarkan petanidapat diketahui melalui fluktuasi harga komoditas yang dikonsumsi oleh petani dan harga barang yang diperlukan untuk memproduksi hasil pertanian (Suyono 2001).Selanjutnya dijelaskan bahwa NTP dipengaruhi oleh tingkat penyerapan tingkat teknologi, tingkat serangan hama dan penyakit serta musim dan harga.

Pengukuran NTP dinyatakan dalam bentuk indeks sebagai berikut :

$$
\mathrm{INTP}=\frac{\mathrm{IT}}{\mathrm{IB}} \mathrm{x} 100
$$


dengan, INTB = Indeks nilai tukar petai; IT = Indeks harga yang diterima petani; IB = Indeks harga yang dbayar petani.

Secara umum ada 3 macam arti angka NTP yaitu :

1. NTP $>100$, berarti petani mengalami surplus. Harga produksinya naik lebih besar dari kenaikkan harga konsumsi. Pendapatan petani naik lebih besar dari pengelurannya.Dengan demikian tingkat kesejahteraan petani lebih baik dibandingkan tingkat kesejahteraan petani sebelumnya.

2. $\mathrm{NTP}=100$, berarti petani mengalami impas/penurunan harga produksi sama dengan persentase kenaikan/penurunan harga barang konsumsi.Tingkat kesejahteraan petani tidak berubah.

3. NTP $<100$, berarti petani mengalami defisit.Kenaikkan harga barang produksi relatif lebih kecil dibandingkan dengan kenaikkan harga barang konsumsi.Tingkat kesejahteraan petani pada suatu periode mengalami penurunan dibandingkan tingkat kesejahteraan petani pada periode sebelumnya. (Badan Pusat Statistik, 2006).

Dalam kajian empiris banyak faktor yang dapat mempengaruhi NTP.Menurut Burhansyah (2011) bahwa faktor yang mempengaruhi nilai tukar petani jagung di Kalimantan Barat adalah harga jagung dan gula, produktifitas, harga pupuk urea, $\mathrm{KCl}$ dan upah kerja.Hasil penelitian di Kalimantan tersebut sejalan dengan kajian Hendayana (2011) yang menyatakan bahwa nilai tukar petani dipengaruhi langsung oleh produktifitas, harga gabah, harga barang konsumsu dab harga pupuk. Variabel indeks nilai tukar petani dapat menjadi indkator tingkat kesejahteraan rumahtangga petani. Indeks nilai tukar petani memberikan pengaruh yang signifikan terhadap ketersediaan beras nasional (Darwanto, 2005).

\section{METODE PENELITIAN}

Jenis data yang diperlukan dalam penelitian ini adalah data time series triwulanan Provinsi Sulawesi Tenggara dalam kurun waktu 2006-2012 yaitu data Inflasi (IHK), PDRB sektor pertanian Sulawesi Tenggara, dan NTP Sulawesi Tenggara. Data tersebutdiperolehdari Badan Pusat stastik (BPS) Provinsi Sulawesi Tenggara dan Kantor Bank Indonesia (BI). 
Variabelyang diamati dalam penelitian ini adalah sebagai berikut: (1) Inflasi Sulawesi Tenggara (IHK); (2) Produk Domestik Regional Brutosektor pertanian (Rp); dan (3) Nilai Tukar Petani (Indeks).

Untuk menjawab dan menjelaskan permasalahan dalam penelitian ini, maka digunakan model regresi berganda (Supranto, 2001). Model tersebut dapat dituliskan sebagai berikut :

$$
Y=a+b_{1} X_{1}+b_{2} X_{2}+e
$$

dimana, $\mathrm{Y}=$ Nilai Tukar Petani (\%); a =Konstanta; $\mathrm{X}_{1}=$ =Inflasi (IHK); $\mathrm{X}_{2}=$ PDRBsektor pertanianharga konstan tahun 2000(Rp); bi=Koefisien regresi, dimana $b_{i}=1,2$; dan $e=$ Error term .

Parameter dugaan diestimasi dengan menggunakan metode pendugaanOrdinary Least Squares (OLS), dengan bantuan perangkat lunak (Software) program Statistic Analysis System (SAS) Versi 6.12. Tanda parameter dugaan yang diharapkan adalah $b_{1}<0$, artinya bahwa variabel $X_{1}$ dan $Y$ mempunyai hubungan negatif. Hal ini menunjukkan apabila variabel $X_{1}$ meningkat (menurun) maka menyebabkan variabel $\mathrm{Y}$ menurun (meningkat). Sedangkan tanda yang diharapkan $b_{2}>0$, artinya bahwa variabel $X_{2}$ dan $Y$ mempunyai hubungan yang positif. Hal ini menunjukkan apabila variabel $X_{2}$ meningkat (menurun) maka variabel Y juga meningkat (menurun).

Untuk mengetahui ketepatan model maka digunakan formulasi dengan uji F (Fisher test).Berhubung estimasi parameter menggunakan Program komputer Statisic Analysis System (SAS) Versi 6.12 maka pengujian model tersebut menggunakan kriteria :

1. Jika probabilitas $F_{\text {hitung }}<$ taraf nyata yang digunakan $(\alpha=0,05)$, maka menujukkan variabel bebas $(X)$ secara bersama-sama berpengaruh nyata terhadap variabel tidak bebas (Y).

2. Jika probabilitas $F_{\text {hitung }}>$ taraf nyata yang digunakan $(\alpha=0,05)$, maka menujukkan variabel bebas $(X)$ secara bersama-sama berpengaruh tidak nyata terhadap variabel tidak bebas $(Y)$.

Selanjunya untuk mengetahui keragaman nilai variabel berpengaruh terhadap variabel terpengaruh menggunakan koefisien determinasi $\left(R^{2}\right)$. Koefisien determinasi menujukkan seberapa baiknya keseluruhan model QE Journal | Vol.03 - No.03 September 2014 - 170 
regresi dalam menerangkan perubahan dalam variabel dependen (Y).Menurut Supranto (1985) bahwa nilai $\mathrm{R}^{2}$ berkisar antara 0 hingga 1, dimana $\mathrm{R}^{2}$ merupakan ukuran ketepatan/kecocokan suatu fungsi garis linear untuk pendekatan suatu kelompok data yang berhubungan dengan data lainnya secara linear. Suatu model dianggap baik jika $\mathrm{R}^{2}$ mendekati 1 .

Untuk mengetahui besarnya pengaruh dari masing-masing variabel bebas $(\mathrm{X})$ terhadap variabel tidak bebas $(\mathrm{Y})$ dilakukan uji t. Kriteria pengujian masing-masing variabelsebagaiberikut :

1. Jika probabilitas thitung $<$ taraf nyata yang digunakan $(\alpha=0,05)$, menunjukkan variabel bebas $(X)$ berpengaruh nyata terhadap variabel tak bebas $(\mathrm{Y})$.

2. Jika probabilitas thitung $>$ taraf nyata yang digunakan $(\alpha=0,05)$, menunjukkan variabel bebas $(X)$ tidak berpengaruh nyata terhadap variabel tak bebas $(\mathrm{Y})$.

Konsep operasional merupakan pengertian dari istilah yang akan digunakan dalam penelitian ini yang juga merupakan batasan yang digunakan memperjelas ruang lingkup penelitian.

1. Inflasimerupakan besarnya laju perubahan harga-harga komoditas secara umum pada tahun tertentu yang diukur dari tahun sebelumnya dengan menggunakan indeks harga konsumen (IHK), dinyatakan dalam persen.

2. Indeks Harga Konsumen (IHK) adalah harga barang di tingkat konsumen yang merupakan indeks harga di pedangang pengecer.

3. PDRB sektor pertanianadalah PDRB Sektor Pertanian triwulan yang merupkan nilai tambah yang dihasilkan oleh seluruh unit usaha suatu wilayah meliputi sub sektor tanaman pangan dan hortikultura, sub sektor perkebunan, sub sektor kehutanan, sub sektor perikanan, sub sektor peternakan, dinyatakan dalam rupiah.

4. NTP adalah indikator yang dihasilkan dari rasio antara harga yang dibayar petani dengan yang diterima petani yang dinyatakan dalam indeks persentase. 
5. Harga yang diterima petani (it) adalah rata-rata harga produsen dari hasil produksi petani sebelum di tambahkan biaya transportasi dan biaya pengepakan ke dalam harga penjualannya.

Harga yang dibayar petani (ib) adalah rata-rata harga eceran barang atau jasa yang dikonsumsi atau dibeli petani, baik untuk memenuhi kebutuhan rumah tangganya sendiri maupun untuk keperluan biaya produksi pertanian.

\section{HASIL DAN PEMBAHASAN}

Dari hasil estimasi model, maka diperoleh persamaan fungsi sebagai berikut :

$$
\mathrm{Y}=250,16-0,45 \mathrm{X}_{1}+0,000123 \mathrm{X}_{2}
$$

dengan, $\quad \mathrm{Y}=$ Nilai Tukar Petani (\%); $\quad \mathrm{X}_{1}=$ IHK (Indeks); $\quad \mathrm{X}_{2}=$ PDRB Sektor Pertanian (Rupiah).

Untuk menguji model yang digunakan, maka dilakukan dengan uji F.Berdasarkan hasil analisis, diperoleh nilai F hitung sebesar 28,53 dengan tingkat probabilitas 0,0001.Tingkat signifikansi F hitung 0,0001 lebih kecil dari taraf nyata yang digunakan $(\alpha=0,05)$, maka sesuai dengan kriteria pengambilan keputusan $\mathrm{H}_{0}$ ditolak dan $\mathrm{H}_{1}$ diterima, hal ini berarti bahwa seluruh variabel bebas $(X)$ yang dimasukkan ke dalam model secara bersama-sama menunjukkan pengaruh yang nyata terhadap NTP di Sultra.

Dari hasil analisis diperoleh nilai koefisien determinasi $\left(\mathrm{R}^{2}\right)$ sebesar 0,85 , berarti bahwa $85 \%$ keragaman variabel tak bebas (Y) dapat dijelaskan oleh keragaman variabel bebas $(X)$ dan sisanya 15\% dijelaskan oleh keragaman variabel lain yang tidak dimasukkan kedalam model. Hal ini juga membuktikan bahwa model regresi linear berganda tersebut dapat digunakan untuk menjelaskan hubungan antara variabel tak bebas (Y) dengan variabel bebas $(X)$ atau dengan kata lain model tersebut layak digunakan.

Koefisien korelasi (R) digunakan untuk mengetahui derajat keeratan hubungan antara variabel tak bebas $(\mathrm{Y})$ dengan variabel-variabel bebas (X). Hasil analisis diperoleh nilai koefisisen korelasi (R) adalah sebesar 0,92 dengan tanda positif dan mendekati angka satu.Oleh karena itu, dapat 
diartikan bahwa antara variabel tak bebas $(Y)$ mempunyai hubungan yang erat atau kuat dengan seluruh variabel bebas $(X)$.

Pengujian hipotesis variabel bebas digunakan untuk melihat pengaruh variabel bebas $(\mathrm{X})$ secara parsial terhadap variabel tak bebas $(\mathrm{Y})$ dengan menggunakan uji t. Ringkasan mengenai hasil analisis regresi linear berganda disajikan pada Tabel 2.

Tabel 2. Nilai KoefisienRegresi Linear Berganda, 2014

\begin{tabular}{lccc}
\hline \multicolumn{1}{c}{ Peubah Penjelas (X) } & $\begin{array}{c}\text { Koefisien } \\
\text { Regresi (b) }\end{array}$ & t hitung & Probabilitas > T \\
\hline Intercep & 270,32 & 6,752 & 0,0001 \\
IHK & $-0,57$ & $-4,753$ & 0,0005 \\
PDRB Sektor Pertanian & 0,00246 & 1,782 & 0,2538 \\
\hline
\end{tabular}

Koefisien Determinasi $\left(\mathrm{R}^{2}\right): 0,85$

Variabel inflasi $\left(X_{1}\right)$ mempunyai koefisien regresi $\left(b_{1}\right)=-0,57$ dengan $t$ hitung $=-4,753$, dengan probabilitasnya adalah 0,0005. Probabilitas $\mathrm{t}$ hitung $(0,0005)$ lebih kecil dari taraf nyata $(\alpha=0,05)$ yang digunakan. Hal ini menunjukkan bahwa variabel IHK $\left(X_{1}\right)$ mempunyai hubungan yang negatif dan berpengaruh nyata terhadap NTP di Sulawesi Tenggara, sehingga dapat diartikan bahwa tinggi atau rendahnya NTP dipengaruhi oleh laju inflasi. Nilai koefisien regresi sebesar $-0,57$ menunjukkan bahwa apabila terjadi kenaikan indeks harga konsumen sebesar 1 satuan, maka akan menyebabkan NTP berkurang sebesar $0,57 \%$ atau jika terjadi kenaikan harga (inflasi) sebesar 1\% maka akan menurunkan NTP sebesar $1,61 \%$ dengan asumsi variabel lain dianggap konstan (ceteris paribus).

Variabel inflasi $\left(\mathrm{X}_{1}\right)$ mempunyai hubungan yang negatif dan berpengaruh nyata terhadap NTP disebabkan karena inflasi yang terjadi akan menyebabkan naiknya harga-harga komoditas barang dan jasa yang dikonsumsi masyarakat secara umum. Beragamnya kebutuhaan petani dengan inflasi yang terjadi menyebabkan indeks biaya hidup itu semakin tinggi sehingga indeks yang harus dibayar bertambah. Semakin tinggi indeks yang harus dibayar maka NTP akan semakin menurun. Selain itu, sifat hasil pertanian yang inelastis (elastisitas permintaan kurang dari satu) menyebabkan produksi hasil pertanian kurang responsif terhadap kenaikan harga. Kalaupun terjadi kenaikan harga (inflasi), naiknya harga QE Journal | Vol.03 - No.03 September 2014 - 173 
hasil pertanian tidak sebanding dengan naiknya harga pada komoditas barang dan jasa pada non sektor pertanian. Dengan sifat hasil pertanian yang inelastis terhadap harga menyebabkan indeks yang diterima relatif menjadi lebih rendah dibandingkan indeks yang dibayar sehingga petani tidak mampu menutupi secara keseluruhan besarnya biaya hidup, dan akibatnya NTP menjadi menurun. Nilai tukar petani yang menurun pada akhirnya akan mempengaruhi kesejahteraan petani. Dapat disimpulkan bahwa inflasi dapat menurunkan NTP karena menyebabkan indeks yang harus dibayar menjadi lebih besar dari indeks yang diterima, sehingga kesejahteraan petani menjadi menurun.

Hal yang dapat dikemukakan mengenai pengaruh negatif inflasi terhadap NTP adanya persoalan transmisi harga.Indeks yang harus dibayar oleh petani cenderung lebih besar pada saat terjadi inflasi. Pada saat terjadi inflasi, kenaikan harga di tingkat pengecer tidak mampu ditransmisikan secara sempurna ke tingkat petani. Artinya pada saat inflasi, pedagang pengecer mendapatkan kenaikan harga yang lebih besar dari petani. Oleh karena itu, indeks yang harus dibayar petani lebih tinggi di bandingkan indeks harga yang di terima. Akibat dari kenaikan harga tersebut, indeks biaya hidup yang harus di bayar petani akan semakin besar dan pada akhirnya akan mempengaruhi kesejahteraan petani.

Kenaikan harga yang terjadi cenderung mengurangi besarnya NTP. Inflasi menyebabkan naiknya harga-harga secara umum sehingga indeks biaya hidup yang harus dibayar menjadi lebih besar di banding indeks yang harus diterima. Akibatnya kesejahteraan petani menurun. Jadi, untuk kondisi seperti ini tampaknya membiarkan harga naik bukanlah cara yang baik untuk meningkatkan kesejahteraan petani. Pemerintah untuk ke depannya harus memikirkan cara agar hasil dari kenaikan harga produk pertanian lebih dirasakan oleh petani (hal ini, antara lain, dapat dilakukan dengan memperbaiki akses petani ke pasar). Bila keadaan ini sudah tercapai, maka diharapkan di masa mendatang kenaikan harga pertanian yang dihasilkan oleh petani akan dapat meningkatkan kesejahteraan petani kita.

Variabel PDRB Sektor Pertanian $\left(\mathrm{X}_{2}\right)$ mempunyai koefisien regresi $\left(\mathrm{b}_{2}\right)=$ 0,00246 dengan t-hitung sebesar 1,782 dan probabilitassebesar 0,2538. Hal ini berarti bahwa variabel PDRB Sektor Pertanian $\left(X_{2}\right)$ mempunyai hubungan yang positif dan berpengaruh tidak nyata terhadap nilai tukar 
petani di Sulawesi Tenggara. Kondisi tersebut disebabkan oleh ketidakseimbangan pelaksanaan pembangunan sektor pertanian yang mana hasilnya itu tidak dinikmati secara merata oleh petani. Selain itu, distribusi pendapatan yang tidak merata di kalangan petani menjadi faktor yang dapat memicu berpengaruh tidak nyatanyaPDRB Sektor pertanian terhadap nilai tukar petani.

Produk Domestik Regional Bruto Sektor Pertanian memberikan kontribusi terbesar dalam pembentukan PDRB total.Besarnya kontribusi tersebut tidak memberikan pengaruh yang nyata terhadap kesejahteraan petani.Ketidakseimbangan nilai konsumsi dengan nilai jual produksi hasil pertanian menjadi faktor pemicu. Kebanyakan petani mengeluarkan konsumsi yang lebih besar dari produksinya, sementara nilai jual produksinya tidak mampu mengimbangi besarnya biaya konsumsi.Konsumsi bersih merupakan jumlah lebih besar dari pada hasil pertanian yang dijual, atau nilai jual hasil pertanian oleh petani relatif lebih kecil dari biaya konsumsi atau dikeluarkan. Seperti halnya hasil pertanian padi sawah, pada saat dijual oleh petani harganya akan berbeda pada saat dibeli untuk dikonsumsi dalam bentuk beras,sehinggabiaya konsumsi lebih besar daripada nilai jual hasil produksinya. Besarnya nilai konsumsi maupun harga jual pada akhirnya akan meningkatkan nilai PDRB, akan tetapi pada NTP tidak memberikan pengaruh yang nyata.

Besarnya kontribusi sektor pertanian dalam PDRB secara total belum memberikan pengaruh terhadap kesejahteraan petani. Walaupun pertumbuhan ekonomi sektor pertanian meningkat akan tetapi NTP tidak mengalami perubahan. Indeks harga yang diterima petani merupakan indeks harga yang menunjukkan perkembangan harga produsen dari hasil-hasil produksi petani. Sedangkan indeks harga yang dibayar petani adalah harga yang menunjukkan perkembangan harga biaya faktor produksi, barang-barang modal yang dibeli dan barang-barang/jasa-jasa untuk kebutuhan rumah tangga petani.Meningkat atau menurunnya indeks tersebut didorong oleh besarnya nilai produksi yang diterima dan indeks konsumsi sebagai akibat dari faktor inflasi.

Melihat indikator PDRB Sektor Pertanian dan NTP tidaklah cukup untuk melihat tingkat kesejahteraan petani karena sifatnya masih makro. Masalah kesejahteraan petani tidak dapat dipecahkan hanya dengan meningkatkan pertumbuhan ekonomi sektor pertanian semata, akan tetapi diperlukan 
pembangunan yang merata disemua sub sektor pertanian sehingga hasilhasilnya dapat dinikmati oleh petani.

\section{SIMPULAN DAN SARAN}

\section{Simpulan}

Berdasarkan pembahasan yang dilakukan maka dapat ditarik kesimpulan sebagai berikut :

1. Inflasi memberikan pengaruh nyata terhadap nilai tukar petani. Pengaruh inflasi terhadap nilai tukar petani bersifat responsif, dimana Inflasi sebesar $1 \%$ akan dapat menurunkan nilai tukar petani sebesar $1,61 \%$.

2. PDRB Sektor Pertanian berpengaruh tidak nyata terhadap nilai tukar petani.

\section{Saran}

Saran yang dapat disampaikan, berdasarkan pembahasan dan kesimpulan adalah :

1. Pengendalian inflasi merupakan tugas penting yang harus diemban Pemerintah agar dampak dari inflasi tersebut tidak mengakibatkan penurunan NTP yang tajam.

2. Mengingat kontribusi sektor pertanian dalam pembangunan di Sultra yang dominan, maka perhatian terhadap pelaku usaha pertanian atau petani melalui program pembangunan yang langsung menyentuh kondisi usahatani seyogyanya lebih memadai agar upaya peningkatan kesejahteraan petani dapat dilakukan secara bertahap dan terencana.

\section{DAFTAR PUSTAKA}

Akhmad, N. A. Achsani, M. Tambunan and S. A. Mulyo. 2013. The Impact of Fiscal Policy on the Regional Economy: Evidence from South Sulawesi, Indonesia. Journal of Applied Sciences Research, 9 (4): 2463-2474. 
Akintunde, Y. W., Adesope and V. O. Okoruwa. 2013. An Analysis of Federal Government Expenditure and Monetary Policy on Agricultural Output in Nigeria. International Journal of Economics, Finance and Management Sciences, 1(6): 310-317.

Bhagat, V. S. (2013). Farmer Terms of Trade and Farmers' Suicides in Maharashtra (India). Asian Journal of Research in Social Sciences and Humanities, 11(3): 216-242.

Boediono. 1993. Ekonomi Makro. BPFE. Yogyakarta.

Burhansyah, R. 2011. Nilai Tukar Petani dan Faktor-Faktor yang Mempengaruhi di Sentra Produksi Jagung Kalimantan Barat. Jurnal Pembangunan Manusia, 5(1).

Darwanto, D.H. 2005. Ketahanan Pangan Berbasis Produksi dan Kesejahteraan Petani. Ilmu Pertanian, 12 (2):152-164.

Ele, I. E., E. O. Iniobong, W. I. Out, and N. B. Itoro. 2014. Analysis of Agricultural Public Capital Expenditure and Agricultural Economic Growth in Nigeria 1961-2010. American Journal of Experimental Agriculture 4(4):443-456.

Erison. 2004. Pengaruh Harga Dasar Gabah dan Harga Pupuk Buatan Terhadap Nilai Tukar Petani Padi di Indonesia. Tesis S2 Program Pascasarjana Unhalu. Kendari.

Hendayana, R. 2011. Makalah disampaikan dalam Seminar Nasional Penelitian dan Pengembangan Agribisnis Berbasis Sumberdaya Lokal dan Teknologi Ramah Lingkungan di BPTP Sulut, 26-27 November 2011. Manado.

Khalwaty. 2000. Inflasi dan Solusinya. PT. Gramedia Pustaka. Jakarta.

Mankiw, N.G. 2003. Pengantar Ekonomi (terjemahan). PT. Erlangga. Jakarta.

Nchuchuwe, F. F. and K. D. Adejuwon. 2012. The Challenges of Agriculture and Rural Development in Africa: The Case of 
Nigeria. International Journal of Academic Research in Progressive Education and Development,1 (3): 45-61.

Sinuhaji, J. 2006. Analisis hubungan Tingkat Inflasi dengan Pengangguran di Indonesia Tahun 1971 - 2004. Tesis Sekolah Pasca Sarjana Universitas Sumatera Utara Medan.

Supranto. 2001. Ekonometrika. Fakultas Ekonomi Universitas Indonesia. Jakarta.

Suyono. 2001. Peningkatan Nilai Tukar Petani di 13 Kota di Indonesia. Buletin Agroekonomi 33 (1) 20-35.

Suparmoko, M. 2000. Pengantar Ekonomi Makro (edisi 4) BPFE.Yogyakarta.

Uger, F. I. 2013. The Impact of Federal Government's Expenditure on the Agricultural Sector in Nigeria. PAT Journal, 9 (1): 114122.

Waluyo, D.E. 2006. Ekonomi Makro. Universitas Muhammadiyah Malang Press. Malang.

Zhang, X., and S. Fan. 2002. Public investment and regional inequality in rural China. Agricultural Economics 30 (2004): 89-100.

Zhllima, E., D.Imami, H. Kächelein, and E. Merkaj. 2013. Impact of Fiscal Policies on Inputs and Production Costs In Greenhouse In Albania. Journal of Central European Agriculture, 14(2): 109-125. 